\title{
SUKU, RAS DAN AGAMA MEMPENGARUHI KEDUDUKAN HAK ASASI MANUSIA DI INDONESIA
}

Ina Ulfa, Dinie Anggraeni Dewi, Yayang Furi Furnamasari

Universitas Pendidikan Indonesia (UPI) Jawa Barat, Indonesia

Email: ulfaina426@upi.edu,dinieanggraenidewi@upi.edu, furi2810@upi.edu

\begin{tabular}{ll}
\hline INFO ARTIKEL & ABSTRAK \\
\hline Diterima & Hak dan kesetaraan bagi setiap orang sering menjadi pusat perhatian bagi \\
22 Juni 2020 & masyarakat. Akan tetapi dalam kehidupan sosial pencapaian kesetaraan \\
Direvisi & akan harkat dan martabat warga negara masih belum menunjukkan \\
6 Juli 2020 & kemajuan yang signifikan. HAM, agama, ras dan suku belum direspons \\
Disetujui & secara serius oleh negara. hak-hak bersuku-suku, ras dan hak memilih \\
10 Juli 2020 & agama bagi setiap orang kerap dilanggar. Pernyataan HAM didalam \\
\hline Kata Kunci: & pancasila mengandung pemikiran bahwa manusia itu diciptakan oleh \\
Hak Asasi & Tuhan Yang Maha Esa yaitu hak kebebasan hidup untuk saling \\
Manusia, Suku, & menghormati, melindungi dan saling membela. Penelitian ini dilatar \\
Ras, Agama & belakangi oleh HAM yang mempengaruhi suku, ras, dan agama karena \\
& hak bagi setiap manusia itu adalah hal yang harus dihormati orang diri \\
& sendiri dinegara Indonesia ini bermacam-macam suku, ras maupun agama \\
& yang membuat kita harus lebih memahami keadaan indonesia ini. \\
& Penelitian ini menggunakan metode kualitatif dengan pendekatan study \\
& case.
\end{tabular}

\begin{abstract}
Rights and equality for everyone are open the center off attention for society. However, in social life, the achievement of equality in the dignity of citizens has not shown significant progress. Human right, religion, race and ethnicity have not been taken seriously by the state, the right of ethnicity, race and the right to choose a religion for everyone are often violated. The statement of Human Right in pancasila contains the thought that humans were created by God Almighty, namely the right to freedom
\end{abstract} Keywords: of life to respect, protect anf defend each other. This research is human motivated by understanding of human right that affect ethnicity, race, and right,etnic,race religion because the right for every human being are thing that must be and religion. respected by people themselves in this country of indonesian.

\section{Pendahuluan}

Hak Asasi Manusia adalah hak dan kebebasan yang fundamental bagi semua orang tanpa memandang kebangsaan, jenis kelamin, asal kebangsaan atau etnis, ras, agama, bahasa, dan status. Hak Asasi Manusia mencakup hak sipil, politik, serta hak untuk hidup, kebebasan, dan kebebasan berekspresi, adapun hal lain sepertihak sosial, hak budaya, hak ekonomi, hak berpendidikan dan hak bekerja.

Menurut (Saf, 2018) HAM merupakan hak yang melekat pada diri manusia yang bersifat kodrati dan fundamental sebagai suatu anugerah Allah yang harus dihormati, dijaga dan dilindungi oleh setiap individu, masyarakat dan negara. kesadaran akan hakhak asasi manusia mengglobal sejak 10 Desember 1948 dengan ditetapkannya oleh 
PBB Deklarasi Universal tentang Hak-hak Asasi Manusia. Deklarasi PBB ini, juga deklarasi-deklarasi sebelumnya, dirancang untuk melindungi kebebasan individu di depan kekuasaan raja, kaum feodal, atau negara yang cenderung dominan dan tersentralisasi.

Hak Asasi dilindungi oleh hukum dan perjanjian internasional dan Deklarasii Universal Hak Asasi Manusia (UDHR) adalah dasar dari sistem internasional untuk melindungi HAM, deklarasi tersebut diadopsi oleh sidang umum PBB pada 10 Desember 1948, untuk melarang kengerian perang dunia ke II agar tidak berkelanjutan 30 pasal UDHR menetapkan hak sipil, politik, sosial, ekonomi, dan budaya semua adalah sebuah visi martabat yang melampaui batas dan otoritas politik dan membuat pemerintah berkomitmen untuk menghormati hak-hak dasar dari setiap orang.

Menurut (Krisnalita, 2018), Hak asasi manusia merupakan hak dasar dan mutlak yang dimiliki setiap orang karena ia adalah manusia. Hak ini ada mengingat rentannya posisi manusia dalam proses bermasyarakat, budaya, ekonomi, sosial dan dimaksudkan untuk memberikan perlindungan. Setiap manusia memiliki hak ini walaupun sejauh mana hak-hak tersebut dipenuhi dalam praktik, sangat bervariasi dari negara ke negara.

Menurut (Risdianto, 2017) Peraturan mengenai Hak Asasi Manusia telah ada sejak disahkannya pancasila sebagai dasar pedoman negara Indonesia. Meskipun secara tersirat baik yang menyangkut hubungan manusia dengan Tuhan maupun manusia dengan manusia. Manusia mempunyai hak untuk memilih apa yang dipercayanyaa karena pempunyai pedoman yaitu adanya sebuah HAM.

Menurut (Nawawi, 2017) Hak Asasi Manusia tidak terlepas dari adanya pengakuan terhadap adanya hukum alam (natural law) yang merupakan cikal bakal munculnya hukum hak asasi manusia yang bersifat universal dan tidak berubah dalam ruang dan waktu hukum itu muncul kepermukaan pada akal manusia yang terlepas dari setiap pandangan agama.

Suatu negara akan memunyai sebuah hukum dalam menyelengarakan sebuah HAM. Penegakan hukum pada hakikatnya merupakan interaksi antara berbagai perilaku manusia yang mewakili kepentingankepentingan yang berbeda dalam bingkai aturan yang telah disepakati bersama. Oleh karena itu, penegakan hukum tidak dapat semata-mata dianggap sebagai proses menerapkan hukum sebagaimana pendapat kaum legalistik. Namun proses penegakan hukum mempunyai dimensi yang lebih luas daripada pendapat tersebut, karena dalam penegakan hukum akan melibatkan dimensi perilaku manusia. Hal tersebut dikutip dari (Fakrulloh, 2005).

Menurut (Iswari, 2017) Penegakan hukum bukanlah semata-mata mengaktualisasikan apa yang ada dalam undang-undang atau mengedepankan sisi kepastian hukum tetapi juga dengan mempertimbangkan nilai-nilai keadilan (justice value), dan kemanfaatan dari penegakan hukum tersebut bagi masyarakat. Penegakan hukum yang hanya mengedepankan sisi kepastian hukum akan berimplikasi pada tidak tercapainya makna hakiki dari penegakan hukum itu sendiri, yaitu untuk memberikan keadilan, kebahagiaan, dan menjamin terpenuhinya Hak Asasi Manusia (HAM).

\section{Metode Penelitian}

Pendekatan penelitian dalam penelitian ini adalah metode kualitatif. Menurut (Creswell \& Poth, 2016) Penelitian kualitatif adalah suatu pendekatan untuk mengeksporasi dan memahami makna yang diberikan oleh individu atau keompok untuk masalah sosial atau manusia. Metode kualitatif lebih mungkin untuk menghasikan hipotesis baru sebagai hasil dari apa yang mereka temukan saat mereka melakukan pekerjaan, karena 
mereka mengaati pola dan hubungan dalam peraturan alami dari pada membuat hipotesis tentang pola dan hubungan dalam seperti sebelumnya.

\section{Hasil dan Pembahasan}

1. Pengertian hak asasi manusia

Sebelum kita mengenal ham sebaiknya kita memahami dulu apa itu hak. Menurut (Saf, 2018) Hak merupakan sesuatu yang harus diperoleh, walaupun pengertian hak dalam berbagai bahasa dan menurut bangsa-bangsa tentunya berbeda satu sama lain disebabkan oleh perbedaan budaya, tradisi, agama dan sistem nilai yang berlaku dalam masyarakat. Namun substansi hak yang merupakan kebenaran yang diperjuangkan oleh setiap orang ataupun kelompok tertentu tidak akan banyak berbeda bahkan memiliki kesamaan yang sangat besar. Perbedaan paham tentang hak tentu tidak lepas dari latar belakang dan cara pandang terhadap kebenaran karena pada dasarnya, masingmasing manusia membawa suatu hal yang mendasar sejak lahir yang disebut dengan fitrah.

Menurut (Utami, 2018) Bangsa Indonesia merupakan Negara kepulauan yang memiliki beranekaragam suku bangsa dan etnis yang memiliki karakteristik tersendiri. Adanya keberagaman bangsa Indonesia di karenakan keadaan geografis Indonesia yang memiliki kepulauan yang di batasi oleh selat dan laut, pengaruh dengan kontak langsung dengan kebudayaan asing sehingga mempengaruhi komunikasi dan memiliki corak agama dan bahasa sendiri, kondisi iklim dan keadaan alam yang berbeda sehingga terbentuk masyarakat yang mengandal laut sebagai sumber kebutuhan hidup dan mata pencaharian. Keberagamanan suku dan bangsa yang ada wilayah di Indonesia merupakan kekayaan dari bangsa Indonesia tersendiri.
Menurut (Krisnalita, 2018) Hak asasi bertujuan menjamin martabat setiap orang. Hak asasi memberikan kekuatan moral untuk menjamin dan melindungi martabat manusia berdasarkan hukum, bukan atas dasar kehendak, keadaan, ataupun kecenderungan politik tertentu. Hak-hak dan kebebasan tersebut memiliki ciri-ciri yakni: tidak dapat dicabut atau dibatalkan, universal, saling terkait satu sama lain dan tidak dapat dipisahpisahkan. Secara sederhana, dapat dikatakan bahwa setiap manusia memiliki sekaligus hak atas kebebasan, rasa aman, dan standar hidup yang layak.

2. Hak memilih agama

Agama adalah suatu pengajaran yang dapat membuat sikap dan prilaku kita manusia dapat berubah lebih baik dan berjalan menapaki jalan hidup mengikuti perintah dari yang maha kuasa atau yang kita yakini masing masing. Ini membuat timbulnya keanekaragaman agama di dunia ini, tetapi dari setiap ajaran ajaran yag diperintahkan memiliki perbedaan yang sangat terlihat, karena seperti yang kita ketahui ada beberapa agama yang diyakini oleh tiap tiap orang di indonesia, yaitu islam, kristen, hindu, budha, konghuchu, dan lain lain. Dalm setiap agama agama tersebut juga terdapat keanekaragaman aliran. Mengenai aliran inilah yang menimbulkan pro dan kontra bagi kita manusia. Timbulnya pro dan kontra tidak lepas dari pengajaran dariorang orang yang dianggap sangat pintar atau orang orang yang dianggap sangat suci dalam aliran aliran tersebut. Hal tersebut dikutip dari (Rumagit, 2013).

Hal ini membuat UU No. 39 Tahun 1999 tentang Hak Asasi Manusia tidak diterapkan dengan baik, karena kekerasan dan diskriminasi antar umat beragama terus meningkat sampai saat ini. Dalam UU No.39 Tahu 1999 tentang Hak Asasi Manusia mengenai kebebasan beragama diatur dalam pasal 22 yang menyatakan bahwa;

a. Setiap orang bebas memeluk agamanya masing masing dan untuk beribadah menurut agama dan kepercayaannya itu.

b. Negara menjamin kemerdekaan setiap orang memeluk agamanya masing 
masing dan untuk beribadah menurut agama dan kepercayaannya itu.

Pancasila mengatur kebebasan hak hak dari tiap tiap warga negara. Dari kelima sila pancasila tersebut menjamin kebebasan beragama, memiliki kedudukan dan sama tinggi, mengutamakan kepentingan bangsa, kebebasan berpendapat, dan hak berkumpul, berhak memiliki kehidupan yang layak dan terhormat. Kemudian dalam UUD 1945 terdapat pasal pasal ynag mengatur hak hak sebagai warga negara dan hak asasi manusia dalam beragama. Yang terdapat dalam pasal pasal E yang berisi sebagai berikut :

a. pasal 28

1) Setiap orang bebas memeluk agama dan ibadah menurut ajaran agamanya, memilih pendidikan, dan pengajaran, memilih pekerjaan, memilih kewarganegaraan, memilih tempat tinggal diwilayah negara dan meninggalkannya serta berhak kembali.

2) Setiap orang atas kebebasan menyakini kepercayaannya menyatakan pikiran dan sikap sesuai dengan hati nuraninya.

3) Setiap orang berhak atas kebebasan berserikat, berkumpul, dan mengeluarkan pendapat.

b. Pasal 29

1) Negara berdasarkan ketuhanan yang maha Esa.

2) Negara menjamin kemerdekaan tiap tiap penduduk untuk memeluk agamanya masing masing dan untuk beribadah menurut agama dan kepercayaannya itu.

Untuk HAM sendiri dalam UUD 1945 diatur dalam pasal 27 sampai dengan pasal 31, tetapi yang berintikan hak untuk beragama terdapat dalam dua pasal diatas yaitu pasal 28 E dan pasal 29 Hak terhadap ras dan suku.

Ras dan etnis tentunya tidak dari kehidupan kita sebagai manusia karena sering manusia itu dikaitkan dengan ras atau etnis untungnya di Indonesia tidak terlalu membeda-bedakan berbeda dengan negara lainnya. Ras adalah persamaana berdasarkan garis biologis garis biologis seperti keturunan atau genetika.
Sudah sejak lama persoalan ras dan HAM itu selalu diperbincangkan dikalangan ahli ahli hukum dan dikalangan para pemikir politik tujuannya untuk mencari suatu konsep yang ideal, tentang perlindungan HAM. Seringkali HAM ini dimaknai secara rendah karena dianggap pedoman moral semata. Menurut (Basyriah, 2019) persoalan diskriminasi rasial sangat potensial terjadi di Indonesia, mengingat jumlah penduduknya yang sangat banyak dengan suku bangsa, ras dan etnis serta tingkat pendidikan yang rendah. Sementara hatus diakui bahwa sampai saat ini upaya yang dilakuakan belom dapat menghentikan diskriminasi rasial.

Menurut (Basyriah, 2019) Negara indonesia merupakan negara maritim. Indonesia terdiri dari beribu-beribu pulau yang salingg terpisah dan terhambatnya hubungan masyarakat antar pulau satu dengan pulau lainnya. Setiap penduduk di pulau satu dengan pulau lainnya mendirikan budaya, suku dan ras yang saling bereda- beda. Hal ini juga yang menyebabkan indonesia terdiri dari beragam budaya, suku, ras di wilayah indonesia. Tetapi indonesia tetap satu sesuai dengan semboyan yaitu "bhineka tunggal ika" yang artinya berbeda beda tetapi tetap satu jua. Walaupun wilayahnya terpisah pisah oleh lautan akan tetapi, indonesia selalu menjunjung tinggi suatu tujuan.

Menurut (Anwar et al., 2019) Keragaman suku bangsa di indonesia dipengaruhi oleh beberapa faktor baik dari luar maupun dari dalam. Bukan hanya faktor dari dalam maupun luar saja tetapi, juga dapat dipengaruhi oleh faktor dari diri sendiri dan masyarakat. Letak wilayah indonesia yang strategis karena berada di antara dua samudra dan dua benua yaitu samudra pasiifk dan samudra hindia, benua asia dan bennua Australia. Dengan adanya wilayah indonesia yang strategis ini indonesia menjadi jalur perdagangan indonesia dan menjadi lalu lintas. Perdagangan di indonesia. Dengan adanya jalur perdagangan ini banyak bangsa asing yang menetap di indonesia dengan berbagai ras, agama, dan kepercayan. Mengakibatkan sebagian dari negara 
Ina Ulfa, Dinie Anggraeni Dewi, Yayang Furi Furnamasari

indonesia yang terpengaruh faktor dari budaya asing. "Bhineka tunggal ika" yang artinya berbeda beda tetapi tetap satu jua.

\section{Kesimpulan}

Hak asasi manusia adalah hak yang dimiliki oleh semua orang secara mutlak. Manusia mempunyai hak untuk dapat memilih agama, suku dan ras yang mereka percaya, karena semua manusia mempunyai kedudukan yang sama dihadapan Tuhan Yang Maha Esa. Manusia dilahirkan dengan martabat dan hak hak yang sama tanpa adanya perbedaan baik itu suku dan ras, begitupun dengan agama yang diyakininya. Setiap warganegara sama kedudukannya di dalam hukum, dengan adanya Hak Asasi Manusia ini sangat berpengaruh terhadap hak-hak yang harus dimiliki oleh manusia terutama terhadap suku, ras dan agama.

\section{Bibliografi}

Anwar, S. T., Manuputty, C. J., \& Wahyuni, W. (2019). Religiositas Agama-agama di Indonesia. Sosioreligius, 4(2). Google Scholar

Basyriah, A. (2019). Meningkatkan Kemampuan Siswa dalam Memahami Berbagai Keragaman Suku di Indonesia melalui Penerapan Metode Pembelajaran Mind Mapping. JPG: Jurnal Penelitian Guru FKIP Universitas Subang, 2(2), 493-501. Google Scholar

Creswell, J. W., \& Poth, C. N. (2016). Qualitative inquiry and research design: Choosing among five approaches. Sage publications. Google Scholar
Sebagai Peluang Menciptakan Keadilan. Jurnal Jurisprudence, 2(1), 22-34. Google Scholar

Iswari, F. (2017). Unsur Keadilan dalam Penegakan Hukum terhadap Pelanggaran Hak Asasi Manusia (HAM) di Indonesia. Pagaruyuang Law Journal, 1(1), 125142. Google Scholar

Krisnalita, L. Y. (2018). Perempuan, Ham dan Permasalahannya di Indonesia. Binamulia Hukum, 7(1), 71-81. Google Scholar

Nawawi, A. (2017). Komnas HAM: Suatu Upaya Penegakan HAM Di Indonesia. PROGRESIF: Jurnal Hukum, 11(1). Google Scholar

Risdianto, D. (2017). Perlindungan Terhadap Kelompok Minoritas di Indonesia dalam Mewujudkan Keadilan dan Persamaan di Hadapan Hukum. Jurnal Rechts Vinding: Media Pembinaan Hukum Nasional, 6(1), 125-142. Google Scholar

Rumagit, S. K. (2013). Kekerasan dan diskriminasi antar umat beragama di Indonesia. Lex Administratum, 1(2). Google Scholar

Saf, M. M. A. (2018). Persoalan Ham Dan Hukum Islam. Al Yasini: Jurnal Keislaman, Sosial, Hukum Dan Pendidikan, 3(1), 34-48. Google Scholar

Utami, N. E. (2018). Nasionalisme Pemersatu Konflik Sosial Di Indonesia (19961999). Kalpataru: Jurnal Sejarah Dan Pembelajaran Sejarah, 3(2), 1-7.Google Scholar

Fakrulloh, Z. A. (2005). Penegakan Hukum

\section{Copyright holder :}

Ina ulfa, Dinie Anggraeni Dewi, Yayang Furi Furnamasari (2020).

First publication right :

Action Research Literate

This article is licensed under:

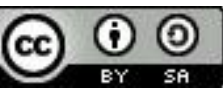

